\title{
High Temperature Oxidation Resistance of Rare Earth Chromite Coated Fe-20Cr and Fe-20Cr-4Al Alloys
}

\author{
Marina Fuser Pillis*, Lalgudi Venkataraman Ramanathan \\ Instituto de Pesquisas Energéticas e Nucleares - IPEN, \\ Materials Science and Technology Center, \\ Av. Prof. Lineu Prestes, 2242, 05508-000 São Paulo - SP, Brazil
}

Received: February 23, 2007; Revised: July 24, 2007

\begin{abstract}
Doped lanthanum chromite has been used in solid oxide fuel cell (SOFC) interconnects. The high costs involved in obtaining dense lanthanum chromite have increased efforts to find suitable metallic materials for interconnects. In this context, the oxidation behavior of lanthanum chromite coated $\mathrm{Fe}-20 \mathrm{Cr}$ and $\mathrm{Fe}-20 \mathrm{Cr}-4 \mathrm{Al}$ alloys at SOFC operation temperature was studied. Isothermal oxidation tests were carried out at $1000{ }^{\circ} \mathrm{C}$ for 20 , 50 and 200 hours. Cyclic oxidation tests were also carried out and each oxidation cycle consisted of 7 hours at $1000^{\circ} \mathrm{C}$ followed by cooling to room temperature. The oxidation measurements and the results of SEM/EDS as well as XRD analyses indicated that lanthanum chromite coated $\mathrm{Fe}-20 \mathrm{Cr}$ and $\mathrm{Fe}-20 \mathrm{Cr}-4 \mathrm{Al}$ alloys were significantly more resistant to oxidation compared with the uncoated alloys.
\end{abstract}

Keywords: interconnects, fuel cells, coating, cyclic oxidation

\section{Introduction}

The solid oxide fuel cell (SOFC) is a multilayered structure and consists of ceramic and metallic materials. Many industrial applications require hundreds of volts and to generate this using SOFC, hundreds of cells and interconnects are assembled in series to form a vertical stack. Interconnects in SOFC link the anode of a cell to the cathode of the next cell in the battery, distribute the gases in the anode and cathode and it also transports electric current between the cells and in the external circuit. Hence, interconnects are an important part of SOFC for long term safe operation ${ }^{1}$. Over the years, a number of metals and ceramic materials have been considered and tested for use as interconnects of planar SOFCs. So far no satisfactory solution has been found. The material used for interconnects is expected to satisfy a variety of requirements such as high density, high electrical and thermal conductivity and high creep resistance 2 .

Until recently, doped $\mathrm{LaCrO}_{3}$ based ceramic interconnects were used in fuel cells ${ }^{1}$. These ceramics were difficult to shape and the cost involved in manufacturing dense interconnects was very high. In recent years the use of metallic interconnects has been gaining ground due to availability of a variety of manufacturing techniques, low shaping costs and adequate thermal conductivity. SOFCs generally operate at around $1000^{\circ} \mathrm{C}$. A number of studies are being carried out to reduce the operating temperatures of SOFCs and the lower temperatures permit metallic interconnects to be considered. The use of coatings or surface treatments is a viable alternative to reduce oxidation rates and extend the useful life of potential alloys as SOFC interconnects. Chromium dioxide forming iron based alloys have been studied as potential materials for interconnects ${ }^{2}$. Nevertheless, the surfaces of the $\mathrm{Fe}-\mathrm{Cr}$ alloys require modification to improve electrical conductivity of the chromium dioxide ${ }^{3}$. The addition of reactive elements such as yttrium, zirconium or cerium to these alloys improves the protective properties of the surface oxides even more ${ }^{4-8}$. Rare earth oxides in the form of dispersions have also been added to these alloys to form protective surface oxides ${ }^{9}$. Coatings of $\mathrm{LaCrO}_{3}$ have been reported to increase the adhesion of the chromium dioxide layer, reduce its growth rate and increase electronic conductivity ${ }^{10}$.

This paper reports the effect of a coating of lanthanum chromite, obtained 'in situ', on the oxidation behavior of an iron-chromium and an iron-chromium-aluminium alloy at $1000{ }^{\circ} \mathrm{C}$.

\section{Methods and Materials}

Two alloys namely $\mathrm{Fe}-20 \mathrm{Cr}$ and $\mathrm{Fe}-20 \mathrm{Cr}-4 \mathrm{Al}$ were prepared in an electric induction furnace and forged at $980{ }^{\circ} \mathrm{C}$. Specimens of these alloys with approximate dimensions of $10 \times 10 \times 2 \mathrm{~mm}$ were cut, ground to 220 mesh, degreased in acetone and weighed.

Lanthanum chromite $\left(\mathrm{LaCrO}_{3}\right)$ coatings were prepared using a mixture of powders of $\mathrm{Cr}_{2} \mathrm{O}_{3}$ and $\mathrm{La}_{2} \mathrm{O}_{3}$. In preliminary tests, samples of this mixture were heated for different duration at 600 and $800{ }^{\circ} \mathrm{C}$ and subsequently analyzed using $\mathrm{X}$ ray diffraction (XRD). In the powder mixtures heated for different duration at $600^{\circ} \mathrm{C}$, the XRD spectra revealed un-reacted $\mathrm{La}_{2} \mathrm{O}_{3}$ and $\mathrm{Cr}_{2} \mathrm{O}_{3}$ as well as $\mathrm{LaCrO}_{4}$ and $\mathrm{La}_{2} \mathrm{CrO}_{6}$. The XRD data of the powder mixture heated at $800{ }^{\circ} \mathrm{C}$ indicated the presence of large quantities of $\mathrm{LaCrO}_{3}$ and a small amount of $\mathrm{LaCrO}_{4}$, besides some $\mathrm{Cr}_{2} \mathrm{O}_{3}$. This indicated that with increase in temperature and time, the lanthanum compounds transformed to $\mathrm{LaCrO}_{3}$. On the basis of these results, the alloy specimen surfaces were coated with the powder mixture and $\mathrm{LaCrO}_{3}$ was formed 'in situ' during the oxidation tests. The specimens were coated by spraying a suspension of the powder mixture in ethanol. Five sides of the specimens were coated and one side remained uncoated. This procedure was adopted due to poor adhesion of the coating. However, after heat treatment the chromite formed and the surface oxides were quite adherent. The average coating thickness was $10-15 \mu \mathrm{m}$. The coated specimens were then weighed and isothermal oxidation tests carried out in a muffle furnace at $1000{ }^{\circ} \mathrm{C}$ for 20,50 and 200 hours. In the cyclic oxidation tests, the uncoated and coated specimens were cycled 15 times and each cycle consisted of holding the specimens for 7 hours at $1000{ }^{\circ} \mathrm{C}$ 
followed by cooling to room temperature. The specimens were weighed after each cycle. The specimen surfaces were examined in a LEO scanning electron microscope (SEM) and micro-regions analyzed using energy dispersive spectroscopy (EDS).

\section{Results and Discussion}

Figure 1 shows the $\mathrm{X}$ ray diffraction spectra of the $\mathrm{Cr}_{2} \mathrm{O}_{3}$ and $\mathrm{La}_{2} \mathrm{O}_{3}$ powder mixture heated for 1,2 and 5 hours at $800{ }^{\circ} \mathrm{C}$. In the spectra, the $\mathrm{LaCrO}_{3}$ peaks are evident indicating its formation. The spectra also reveals $\mathrm{Cr}_{2} \mathrm{O}_{3}$ peaks, but no $\mathrm{La}_{2} \mathrm{O}_{3}$ peaks, indicating thus an excess of only the former in the mixture.

The weight gain vs. time curves of the two alloys, with and without $\mathrm{LaCrO}_{3}$ coating at $1000{ }^{\circ} \mathrm{C}$ are shown in Figure 2. None of the specimens exhibited oxide spallation. The weight gain of the $\mathrm{Fe}-20 \mathrm{Cr}$ alloy specimen was the highest and that of the $\mathrm{LaCrO}_{3}$ coated $\mathrm{Fe}-20 \mathrm{Cr}-4 \mathrm{Al}$ alloy specimens the lowest, indicating higher oxidation resistance of the latter. The oxide formed on the uncoated and coated $\mathrm{Fe}-20 \mathrm{Cr}$ alloy specimens was mainly chromium dioxide and that on the $\mathrm{Al}$ containing alloys, aluminium oxide. The amount of chromium dioxide or aluminium oxide formed on the uncoated alloy specimens was more than that on the coated alloy specimens. Growth of chromium dioxide or aluminium oxide on the coated alloy specimens was inhibited by incorporation of $\mathrm{La}^{2+}$ ions in the growing scale. This La ion segregates to the grain boundaries in the scale

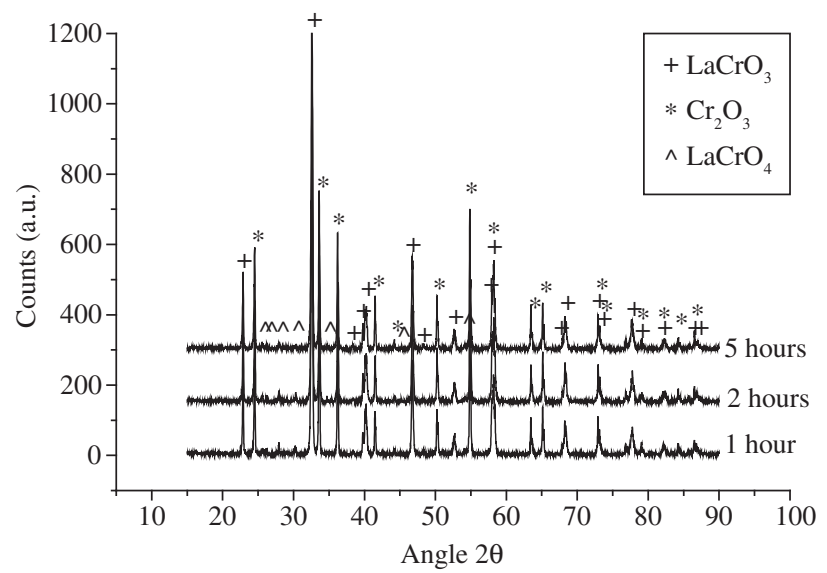

Figure 1. $\mathrm{X}$ ray diffraction spectra of the $\mathrm{Cr}_{2} \mathrm{O}_{3}$ and $\mathrm{La}_{2} \mathrm{O}_{3}$ powder mixture heated in air for 1,2 and 5 hours at $800{ }^{\circ} \mathrm{C}$.

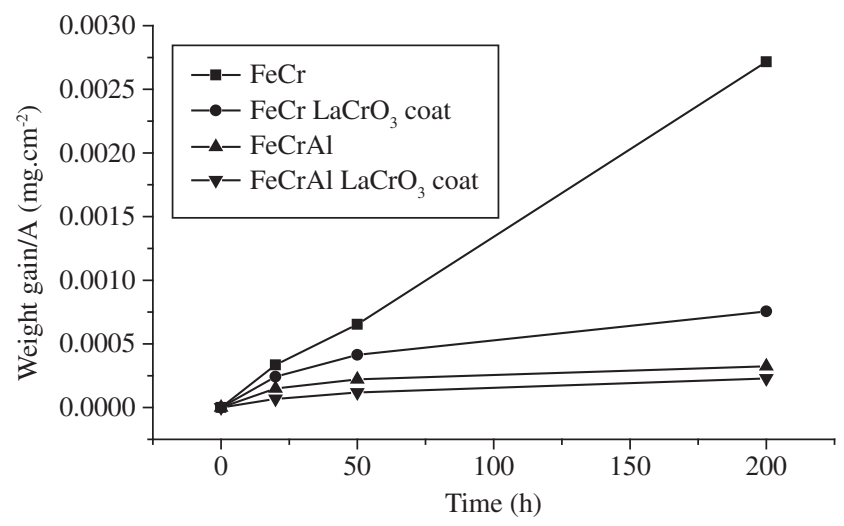

Figure 2. Oxidation curves of alloys $\mathrm{Fe}-20 \mathrm{Cr}$ and $\mathrm{Fe}-20 \mathrm{Cr}-4 \mathrm{Al}$ with and without $\mathrm{LaCrO}_{3}$ coating. and blocks substrate-cation diffusion, thus inhibiting scale growth ${ }^{11}$. This blocking effect is due to the higher ionic radius of the La ion, compared with the ionic radii of the substrate cations.

Figure 3 a shows the cross section of $\mathrm{Fe}-20 \mathrm{Cr}$ specimens oxidized for 200 hours at $1000{ }^{\circ} \mathrm{C}$. The surface layer is irregular with voids,

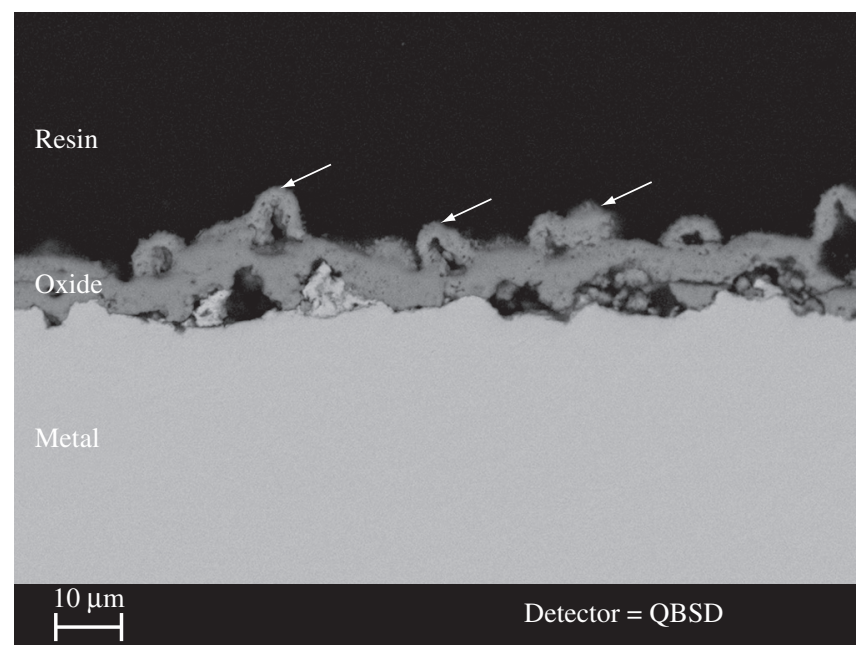

(a)

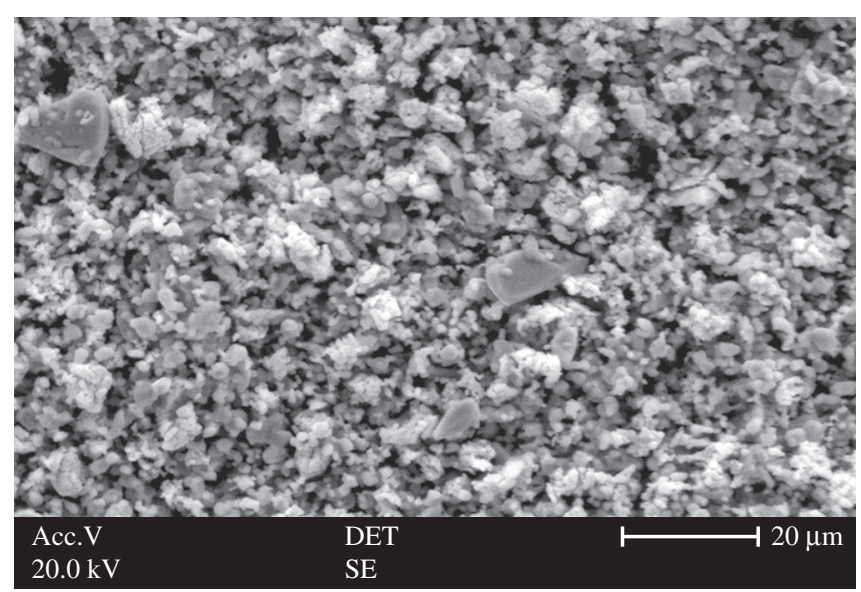

(b)

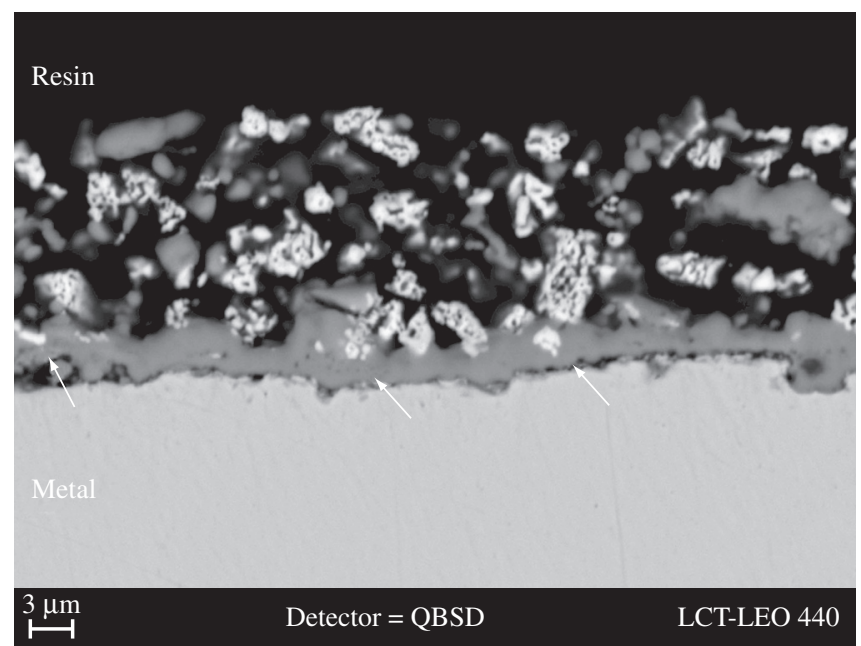

(c)

Figure 3. a) Cross section of $\mathrm{Fe}-20 \mathrm{Cr}$ after 200 hours of oxidation at $1000^{\circ} \mathrm{C}$; b) Surface of $\mathrm{LaCrO}_{3}$ coated Fe-20Cr after 200 hours of oxidation at $1000{ }^{\circ} \mathrm{C}$; and c) Cross section of (b). 
both at the interface and in the alloy. EDS indicated Mn in the outer surface of the layer (arrows). XRD data indicated that the oxide layer was mainly $\mathrm{Cr}_{2} \mathrm{O}_{3}$ and the outer part of the oxide layer contained $\mathrm{MnCr}_{2} \mathrm{O}_{4}$. This indicates that $\mathrm{Mn}$ diffuses faster than $\mathrm{Cr}$ through the $\mathrm{Cr}_{2} \mathrm{O}_{3}$ scale $^{12}$. The oxide layer was about $10 \mu \mathrm{m}$ in thickness. The surface and cross section of $\mathrm{LaCrO}_{3}$ coated $\mathrm{Fe}-20 \mathrm{Cr}$ after 200 hours at $1000{ }^{\circ} \mathrm{C}$ are shown in Figures $3 \mathrm{~b}$ and $3 \mathrm{c}$. The coating is porous and adherent. The oxide layer (grey), about $3.5 \mu \mathrm{m}$ thick, revealed particles from the coating and XRD analysis of this layer suggests the formation of $\mathrm{MnCr}_{2} \mathrm{O}_{4}, \mathrm{Cr}_{2} \mathrm{O}_{3}$ and $\mathrm{LaCrO}_{3}$. EDS and XRD analysis data indicated that the dark particles in the oxide layer were un-reacted $\mathrm{Cr}_{2} \mathrm{O}_{3}$ and the light particles, $\mathrm{LaCrO}_{3}$.

The cross section of uncoated and coated Fe-20Cr-4Al alloy specimens oxidized for 200 hours at $1000{ }^{\circ} \mathrm{C}$ are shown in Figures $4 \mathrm{a}$ and $4 \mathrm{~b}$. In Figure $4 \mathrm{a}$, besides the $\alpha-\mathrm{Al}_{2} \mathrm{O}_{3}$ layer, interfacial voids, formed during growth of the alumina layer, can be observed ${ }^{13}$. XRD analysis of the surface layer seen in Figure $4 \mathrm{~b}$ indicated the formation of $\mathrm{LaCrO}_{3}$ and $\alpha-\mathrm{Al}_{2} \mathrm{O}_{3}$.

The results of cyclic oxidation of the two alloys, with and without the $\mathrm{LaCrO}_{3}$ coating, are shown in Figure 5. Neither of the alloys, with or without the coatings exhibited oxide spalling. The coated alloys exhibited a marked change in weight gain after the second cycle, where as the uncoated alloy specimens exhibited the change in weight gain right after the first cycle and this weight gain was maintained even after 15 cycles. This weight change could be attributed to formation of lanthanum chromite and the initiation of scale formation during the first cycle followed by further scale growth during the second cycle. The peak in the change in weight gain of the uncoated $\mathrm{Fe}-20 \mathrm{Cr}$ alloy after the $6^{\text {th }}$ cycle was due probably to oxide cracking and formation of new oxide.

The cross sections of uncoated and $\mathrm{LaCrO}_{3}$ coated $\mathrm{Fe}-20 \mathrm{Cr}$ specimens after 15 cycles of oxidation at $1000^{\circ} \mathrm{C}$ are shown in Figures $6 \mathrm{a}$ and $6 \mathrm{~b}$. In Figure $6 \mathrm{a}$, voids, both interfacial and in the oxide can be observed. These features are similar to those observed in specimens oxidized isothermally.

Figure $7 \mathrm{a}$ and $7 \mathrm{~b}$ show the cross sections of the uncoated and coated Fe-20Cr-4Al specimens after 15 cycles of oxidation at $1000{ }^{\circ} \mathrm{C}$. Most of the features are identical to those observed in specimens of this alloy that were oxidized isothermally. Particles of the coating can be seen in the oxide layer that grew from the alloy substrate.

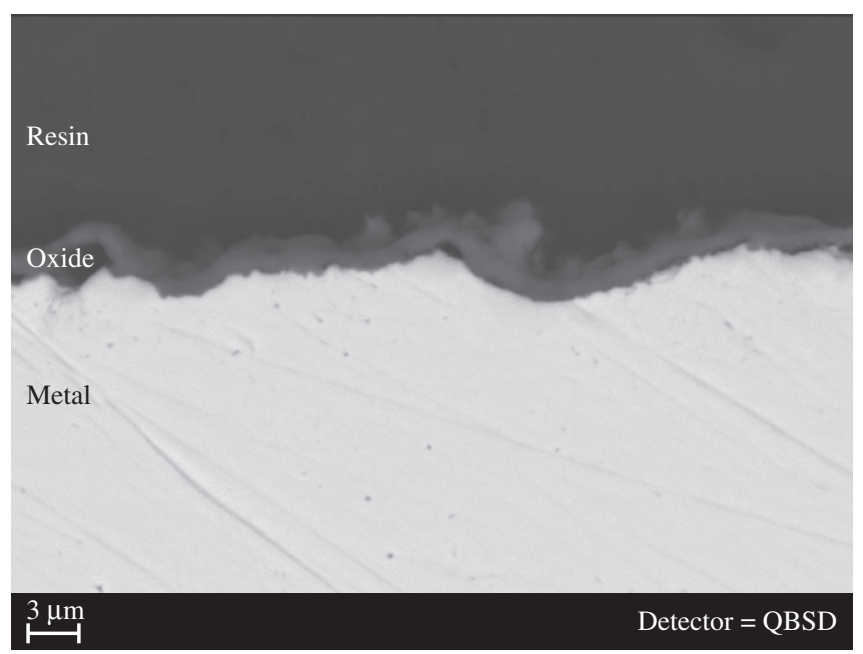

(a)

\section{Conclusions}

1. Lanthanum chromite coatings on Fe-20Cr and Fe-20Cr-4Al alloy specimens were obtained by 'in-situ' synthesis at $800{ }^{\circ} \mathrm{C}$ from a mixture of $\mathrm{La}_{2} \mathrm{O}_{3}$ and $\mathrm{Cr}_{2} \mathrm{O}_{3}$;

2. The isothermal and cyclic oxidation tests revealed that the lanthanum chromite coated Fe-20Cr and Fe-20Cr-4Al alloy specimens were significantly more resistant to oxidation than the uncoated specimens of the same alloys;

3. The XRD and SEM/EDS measurements on oxidized lanthanum chromite coated $\mathrm{Fe}-20 \mathrm{Cr}$ and $\mathrm{Fe}-20 \mathrm{Cr}-4 \mathrm{Al}$ alloy specimens revealed the formation of thin adherent chromium dioxide and alumina respectively;

4. The increased oxidation resistance of lanthanum chromite coated specimens is due to incorporation of La ions in the oxide scales formed during oxidation; and

5. The results of this investigation indicate that lanthanum chromite coated $\mathrm{Fe}-\mathrm{Cr}$ and $\mathrm{Fe}-\mathrm{Cr}-\mathrm{Al}$ alloys can be considered for use as interconnects in SOFC.

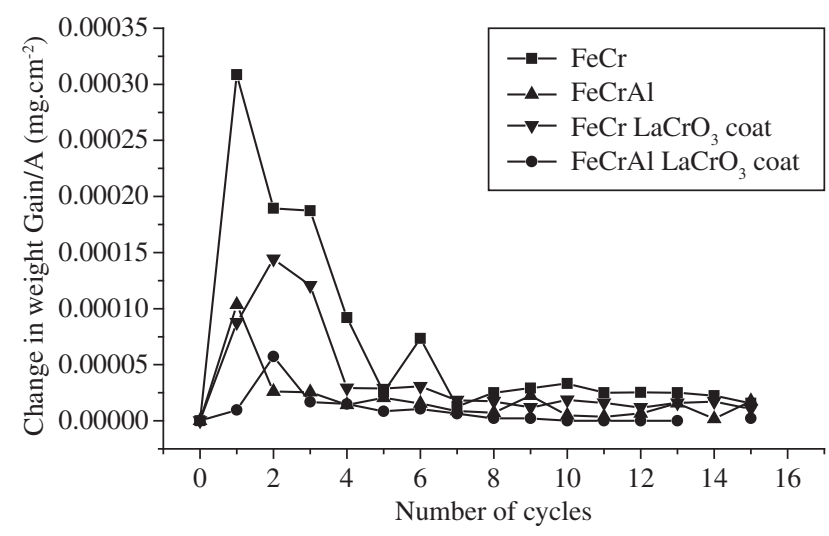

Figure 5. Cyclic oxidation curves of the coated and uncoated alloys. Each cycle consisted of 7 hours at $1000{ }^{\circ} \mathrm{C}$ followed by cooling to room temperature.

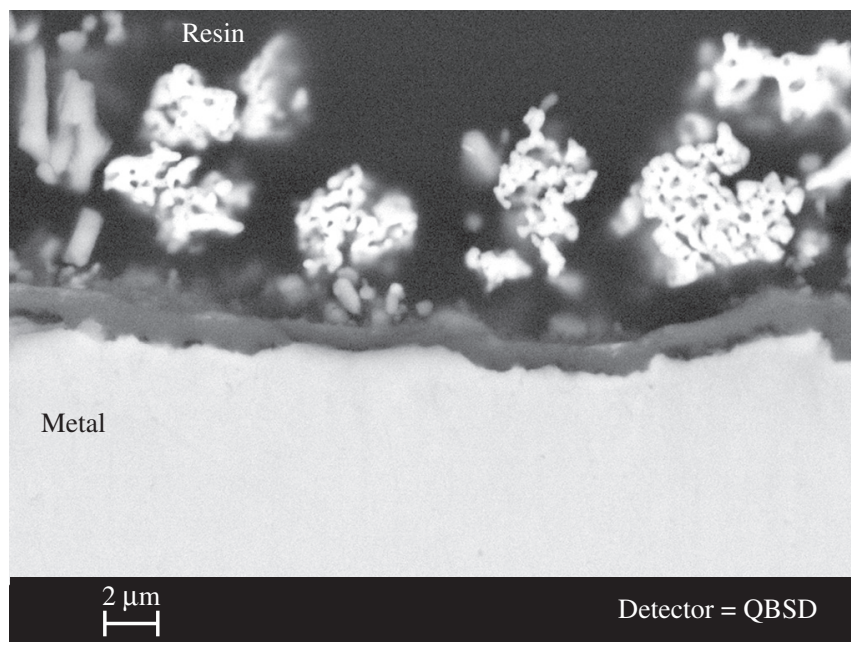

(b)

Figure 4. Cross section of Fe-20Cr-4Al oxidized for 200 hours at $1000{ }^{\circ} \mathrm{C}$. a) Uncoated; and b) $\mathrm{LaCrO}_{3}$ coated. 


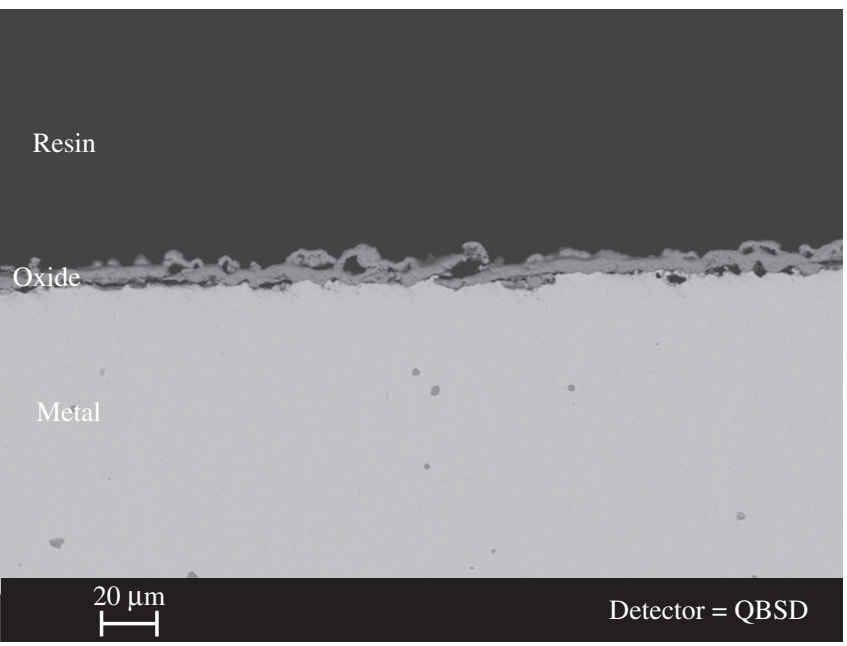

(a)

Figure 6. Cross section of Fe-20Cr after 15 cycles of oxidation in air at $100{ }^{\circ} \mathrm{C}$. a) Uncoated; and b) $\mathrm{LaCrO}_{3}$ coated.

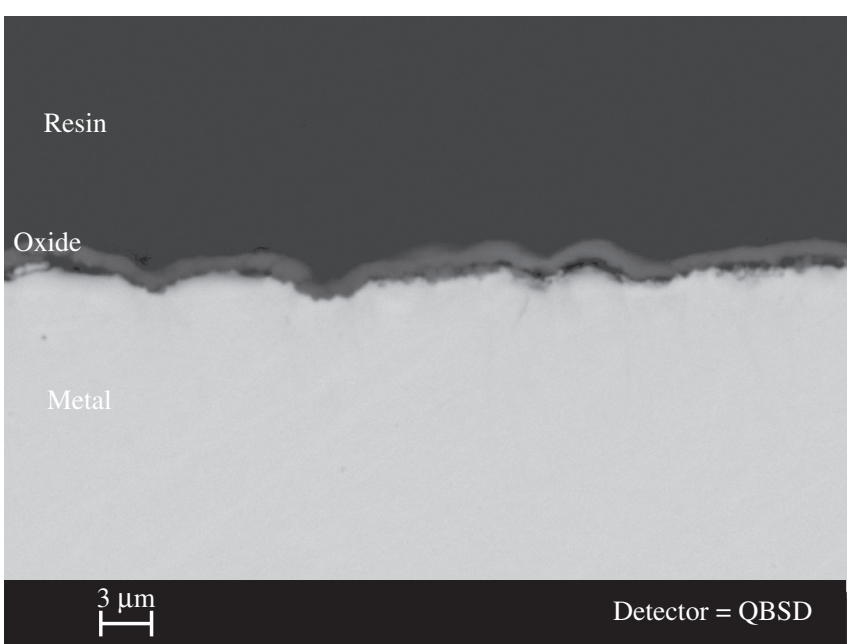

(a)

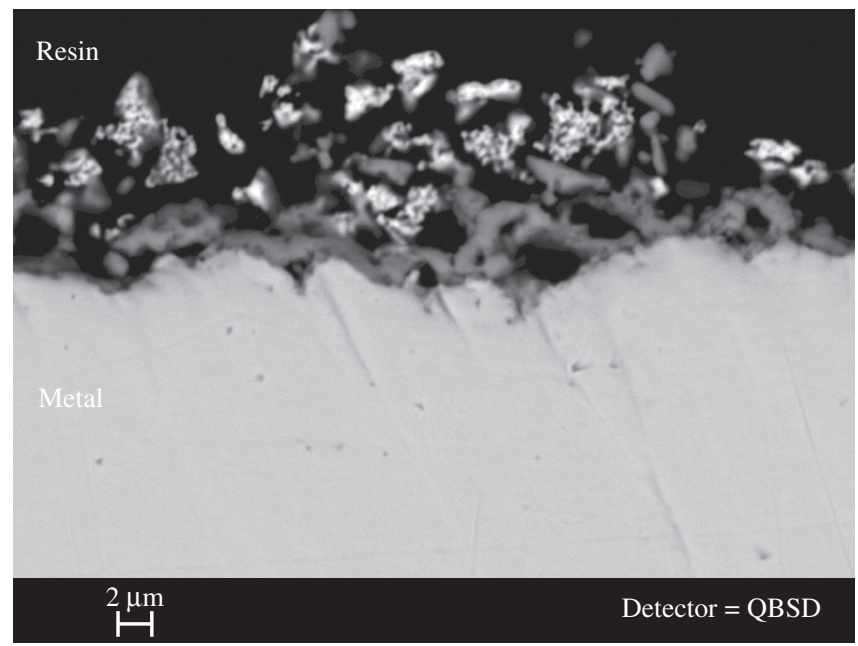

(b)

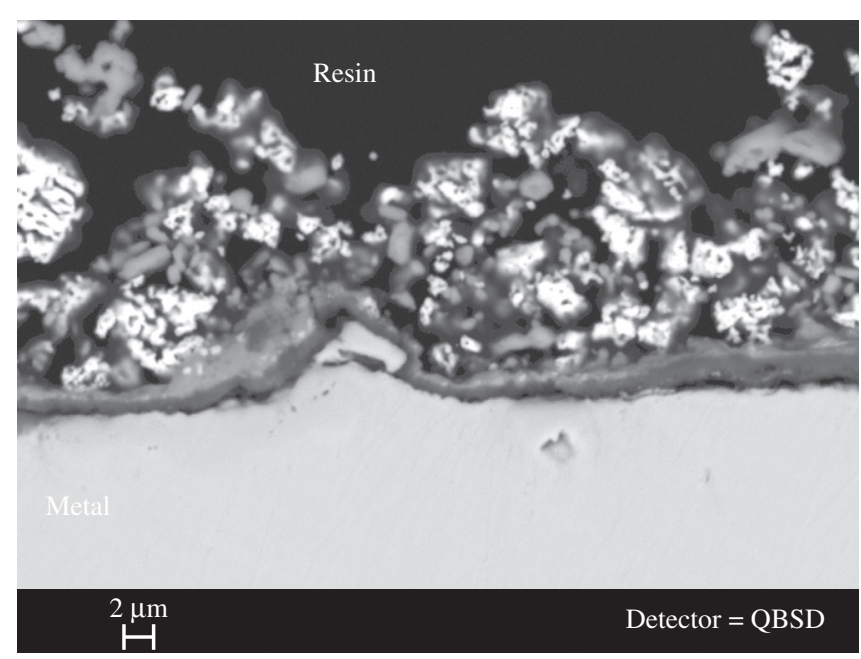

(b)

Figure 7. Cross section of $\mathrm{Fe}-20 \mathrm{Cr}-4 \mathrm{Al}$ after 15 cycles of oxidation in air at $1000{ }^{\circ} \mathrm{C}$. a) uncoated; and b) $\mathrm{LaCrO}_{3}$ coated.

\section{References}

1. Brylewski T, Nanko M, Maruyama T, Przybylski K. Application of Fe$16 \mathrm{Cr}$ ferritic alloy as interconnect in a solid oxide fuel cell. Solid State Ionics. 2001; 143(2):131-150.

2. Badwal SPS, Deller R, Foger K, Ramprakash Y, Zhang JP. Interaction between chromia forming alloy interconnects and air electrode of solid oxide fuel cells. Solid State Ionics. 1997; 99(3/4):297-310.

3. Kadowaki T, Shiomitsu T, Matsuda E, Nakagawa H, Tsuneizumi H. Applicability of heat resisting alloys to the separator of planar type solid oxide fuel cell. Solid State Ionics. 1993; 67(1-2):65-69.

4. Pillis MF, de Araújo EG, Ramanathan LV. Effect of Addition of Rare Earth Concentrates on Oxidation Resistance of AISI 304L. Materials Science Forum. 2006; 530-531:99-104.

5. Pillis MF, Ramanathan LV. Effect of alloying additions and preoxidation on high temperature sulphidation resistance of iron-chromium alloys. Surface Engineering. 2006; 22(2):129-137.

6. Brossard J-M, Balmain J, Cresus J, Bonnet G. Characterization of thin solid films containing yttrium formed by electrogeneration of base for high temperature corrosion applications. Surface and Coatings Technology. $2004 ; 185(2 / 3): 275-282$.
7. Zhu L, Peng X, Yan J, Wang F. Oxidation of a Novel Chromium Coating with $\mathrm{CeO}_{2}$ Dispersions. Oxidation of Metals. 2004; 62(5/6):411-426.

8. Chevalier S, Bonnet G, Larpin JP. Metal-organic chemical vapour deposition of $\mathrm{Cr}_{2} \mathrm{O}_{3}$ and $\mathrm{Nd}_{2} \mathrm{O}_{3}$ coatings. Oxide growth kinetics and characterization. Applied Surface Science. 2000; 167(3-4):125-133.

9. Pillis MF, de Araújo EG, Ramanathan LV. Effect of Addition of Rare Earth Oxide Concentrates on Oxidation Behavior of AISI 304L Stainless Steel. TMS Letters. 2004; 1(3):57-58.

10. Zhu JH, Zhang Y, Basu A, Lu AG, Paranthaman M, Lee DF, Payzant EA. $\mathrm{LaCrO}_{3}$-based coatings on ferritic stainless steel for solid oxide fuel cell interconnect applications. Surface and Coatings Technology. 2004; 177-178:65-72.

11. Fernandes SMC, Ramanathan LV. Rare earth oxide coatings to control high temperature degradation of chromia forming alloys. Materials Research. 2004; 7(1):135-139.

12. Wild RK. High temperature oxidation of austenitic stainless steel in low oxygen pressure. Corrosion Science. 1977; 17(2):87-93.

13. Tolpygo VK, Grabke HJ. Microstructural characterization and adherence of $\alpha-\mathrm{Al}_{2} \mathrm{O}_{3}$ oxide scales on $\mathrm{FeCrAl}$ and FeCrAlY alloys. Oxidation of Metals. 1994; 41(5/6):343-364. 